\title{
RELATIONSHIP BETWEEN DENTAL ANXIETY AND PAIN EXPERIENCE DURING DENTAL EXTRACTIONS
}

\author{
SANTHOSH KUMAR MP* \\ Department of Oral and Maxillofacial Surgery, Saveetha Dental College and Hospital, Chennai, Tamil Nadu, India. \\ Email: santhoshsurgeon@gmail.com
}

Received: 08 December 2016, Revised and Accepted: 22 December 2016

\section{ABSTRACT}

Objective: To assess the effects of anxiety on pain experienced during dental extractions.

Methods: A prospective study was conducted during the academic year July-September 2016, randomly among 60 dental patients who visited the outpatient Department of Oral and Maxillofacial Surgery, Saveetha Dental College, Saveetha University, Chennai, for single tooth extraction. Anxiety was measured using the Hamilton anxiety rating scale. The pain was measured using the pain visual analog scale (VAS) for the level of pain perceived during extraction. Data collected were analyzed with Statistical Package for Social Sciences for Windows, Version 16.0 (SPSS Inc., Chicago, IL, USA) and results obtained.

Results: From regression analysis, $\mathrm{R}^{2}=0.605$ which meant that the independent variable (anxiety) explained $60.50 \%$ of the variability of the dependent variable (pain) with significant t-value. There was a statistically significant correlation between VAS and total anxiety score ( $<<0.05$ ). This strongly suggests that an increase in pain level is associated with an increase in anxiety level.

Conclusion: Pre-operative dental anxiety is a major predictor of pain experienced by patients during dental extractions. Hence, it is an important to reduce anxiety before treatment to reduce pain during the treatment. Pharmacologic modalities like sedation can be used for reducing anxiety and pain related to the treatment in indicated patients.

Keywords: Dental anxiety, Sedation, Anesthesia, Pain, Tooth extraction.

(C) 2017 The Authors. Published by Innovare Academic Sciences Pvt Ltd. This is an open access article under the CC BY license (http://creativecommons. org/licenses/by/4. 0/) DOI: http://dx.doi.org/10.22159/ajpcr.2017.v10i3.16518

\section{INTRODUCTION}

Dental extractions are the commonly performed procedures in dental clinics. An ideal tooth extraction is defined as painless removal of the whole tooth or tooth root with minimal trauma to the investing tissues so that the wound heals uneventfully and no post-operative prosthetic problem is created. Dental anxiety and fear are common among patients, and dental extractions are one of the most feared procedures. Klingberg and Broberg described dental anxiety as a state of apprehension that something dreadful is going to happen in relation to dental treatment or certain aspects of dental treatment [1]. Dental anxiety and fear are said to enhance pain during dental treatment. It may interfere with patients' compliance during treatment resulting in poor dental and oral health [2].

Several factors may influence the perception of pain as it is a complex process. Pain is not only determined by nociceptive stimulus but also by cognitive and emotional factors [3]. According to Rhudy and Meagher emotional states highly modulate human pain reactivity [4]. The positive relationship between anxiety and dental treatment pain as proven by several studies [5-9] state that major generators of anxiety are anesthetic injections and minor oral surgeries such as tooth extraction $[10,11]$. The rationale of this study was to estimate the anxiety and pain levels of patients during extraction and assess the effects of anxiety on pain experienced during dental extractions done in our college.

\section{METHODS}

A prospective study was conducted during the academic year JulySeptember 2016 among the dental patients who visited the outpatient department of oral and maxillofacial surgery, Saveetha Dental College, Saveetha University, Chennai. This study was conducted randomly on 60 patients who required single tooth extraction for various reasons such as pulpitis, mobility, root stump, periodontal disease, and fractured teeth. Demographic details of the patients - such as age, sex, occupation, and educational qualification - were recorded.

For each patient anxiety and pain levels were measured using questionnaires with the help of patients. Anxiety was measured using the Hamilton anxiety rating scale:

0 - no anxiety

1 - Mild anxiety

2 - Moderate anxiety

3 - Severe anxiety

4 - Very severe anxiety.

The pain was measured using the pain visual analog scale (VAS) graded $0-10$, the level of pain perceived during extraction:

Score $0 / 1 / 2$ : No pain

Score 3/4: Moderate pain

Score 5/6: Depressing pain

Score 7/8: Horrible pain

Score 9/10: Excruciating pain.

Extractions were done by a single dentist on all the patients, and data were recorded. Data collected were analyzed with Statistical Package for Social Sciences for Windows, Version 16.0 (SPSS Inc., Chicago, IL, USA) and results obtained. To describe the data descriptive statistics frequency analysis, percentage analysis was used for categorical variables and the mean and standard deviation were used for continuous variables. To find the significance in categorical data, Chi-square test 
was used. In the above statistical tool the probability value, $\mathrm{p}<0.05$ is considered as significant level.

\section{RESULTS}

In our study, 60 patients ( 29 males and 31 females) in the age range of 21-74 years participated and underwent single tooth extractions. Various data were compiled and calculated as shown below in the following tables. Tables 1-3 give frequency distribution of values for sex, anxiety, and pain, respectively. Tables 4-6 give descriptive statistics age-wise and for males and females, respectively. Table 7 describes correlation between anxiety and pain, and Table 8 gives results for Chisquare tests.

\section{Regression analysis: Anxiety versus pain}

Regression analysis was performed to obtain the relationship between pain and anxiety level. It is evident from the below tables that the

Table 1: Sex

\begin{tabular}{lllll}
\hline Valid & Frequency & Percent & Valid percent & $\begin{array}{l}\text { Cumulative } \\
\text { percent }\end{array}$ \\
\hline Male & 29 & 48.3 & 48.3 & 48.3 \\
Female & 31 & 51.7 & 51.7 & 100.0 \\
Total & 60 & 100.0 & 100.0 & \\
\hline
\end{tabular}

Table 2: Anxiety

\begin{tabular}{lllll}
\hline Valid & Frequency & Percent & Valid percent & $\begin{array}{l}\text { Cumulative } \\
\text { percent }\end{array}$ \\
\hline No anxiety & 5 & 8.3 & 8.3 & 8.3 \\
Mild & 19 & 31.7 & 31.7 & 40.0 \\
Moderate & 23 & 38.3 & 38.3 & 78.3 \\
Severe & 13 & 21.7 & 21.7 & 100.0 \\
Total & 60 & 100.0 & 100.0 & \\
\hline
\end{tabular}

Table 3: Pain

\begin{tabular}{lllll}
\hline Valid & Frequency & Percent & Valid percent & $\begin{array}{l}\text { Cumulative } \\
\text { percent }\end{array}$ \\
\hline 0 & 5 & 8.3 & 8.3 & 8.3 \\
1 & 4 & 6.7 & 6.7 & 15.0 \\
2 & 3 & 5.0 & 5.0 & 20.0 \\
4 & 1 & 1.7 & 1.7 & 21.7 \\
5 & 18 & 30.0 & 30.0 & 51.7 \\
6 & 3 & 5.0 & 5.0 & 56.7 \\
7 & 7 & 11.7 & 11.7 & 68.3 \\
8 & 19 & 31.7 & 31.7 & 100.0 \\
Total & 60 & 100.0 & 100.0 & \\
\hline
\end{tabular}

Table 4: Descriptive statistics

\begin{tabular}{llllll}
\hline Sex & N & Minimum & Maximum & Mean & $\begin{array}{l}\text { Standard } \\
\text { deviation }\end{array}$ \\
\hline Age & 60 & 21 & 74 & 42.6 & 13.478 \\
Valid N (list wise) & 60 & & & & \\
\hline
\end{tabular}

Table 5: Descriptive statistics ${ }^{\mathrm{a}}$

\begin{tabular}{llllll}
\hline Sex & N & Minimum & Maximum & Mean & $\begin{array}{l}\text { Standard } \\
\text { deviation }\end{array}$ \\
\hline Age & 29 & 21 & 74 & 45.28 & 14.217 \\
Valid N (list wise) & 29 & & & & \\
\hline aSex=Male & & & & &
\end{tabular}

$\mathrm{R}^{2}=0.605$ which means that the independent variable (anxiety) explains $60.50 \%$ of the variability of the dependent variable (pain) with significant t-value (Tables 9-13). This strongly suggests that an increase in pain level is associated with an increase in anxiety level.

The relationship between patients' pain responses to dental extraction indicated by the VAS and dental anxiety scores were evaluated by the Spearman's rank correlation coefficient for total anxiety scores. There was a statistically significant correlation between VAS and total anxiety score $(\mathrm{p}<0.05)$.

\section{DISCUSSION}

Anxiety can be defined as an unpleasant subjective bodily state that acts as an alerting reaction and coping mechanism to some impending event $[12,13]$. Gilhotra et al. [14] have elaborated various neurochemicals involved in the pathology of anxiety. Anxiety is not always detrimental to a person's capabilities but often is normal and necessary to help prepare for a crisis situation.

Pain is an unpleasant sensory and emotional experience associated with actual or potential tissue damage. Thakur and Srivastava [15] in their review article elaboratively explains about the mechanisms of

Table 6: Descriptive statistics ${ }^{\mathrm{a}}$

\begin{tabular}{llllll}
\hline Sex & N & Minimum & Maximum & Mean & $\begin{array}{l}\text { Standard } \\
\text { deviation }\end{array}$ \\
\hline Age & 31 & 21 & 60 & 40.10 & 12.459 \\
Valid N (list wise) & 31 & & & & \\
\hline aSex=Female & & & & &
\end{tabular}

Table 7: Anxiety*pain cross tabulation

\begin{tabular}{llllllllll}
\hline Count & \multicolumn{1}{l}{ Anxiety } & \multicolumn{1}{l}{ Pain } & & & & & & & \multirow{2}{*}{ Total } \\
\cline { 2 - 7 } & $\mathbf{0}$ & $\mathbf{1}$ & $\mathbf{2}$ & $\mathbf{4}$ & $\mathbf{5}$ & $\mathbf{6}$ & $\mathbf{7}$ & $\mathbf{8}$ & \\
\hline No anxiety & 2 & 2 & 0 & 0 & 1 & 0 & 0 & 0 & 5 \\
Mild & 3 & 1 & 2 & 1 & 7 & 1 & 0 & 4 & 19 \\
Moderate & 0 & 1 & 0 & 0 & 10 & 2 & 5 & 5 & 23 \\
Severe & 0 & 0 & 1 & 0 & 0 & 0 & 2 & 10 & 13 \\
Total & 5 & 4 & 3 & 1 & 18 & 3 & 7 & 19 & 60 \\
\hline
\end{tabular}

${ }^{*}$ Distribution $=60$

Table 8: Chi-square tests

\begin{tabular}{llll}
\hline Parameters & Value & df & $\begin{array}{l}\text { Asymp. } \\
\text { significant (2-sided) }\end{array}$ \\
\hline Pearson Chi-square & $48.257^{\mathrm{a}}$ & 21 & 0.001 \\
Likelihood ratio & 51.944 & 21 & 0.000 \\
Linear-by-linear association & 22.356 & 1 & 0.000 \\
Number of valid cases & 60 & & \\
\hline
\end{tabular}

a28 cells $(87.5 \%)$ have expected count $<5$. The minimum expected count is 0.08

Table 9: Correlations

\begin{tabular}{lll}
\hline Spearman's rho & Anxiety & Pain \\
\hline $\begin{array}{l}\text { Anxiety } \\
\text { Correlation coefficient }\end{array}$ & 1.000 & $\begin{array}{l}0.605^{* *} \\
\text { Significant (2-tailed) } \\
\text { N }\end{array}$ \\
$\begin{array}{ll}\text { Pain } \\
\text { Correlation coefficient }\end{array}$ & 60 & 60 \\
$\quad \begin{array}{l}\text { Significant (2-tailed) } \\
\text { N }\end{array}$ & $0.005^{* *}$ & 1.000 \\
**Correlation is significant at the 0.01 level (2-tailed) & 60 \\
\hline
\end{tabular}

**Correlation is significant at the 0.01 level (2-tailed) 
acute and chronic pain and the underlying peripheral as well as central pathogenic mechanisms involved. Pain is usually associated to dental treatment, and several factors may influence its perception because it is a complex process [16].

In terms of the effects of anxiety on the perception of pain, it can be said that anxiety acts concomitantly with pain; as anxiety increases, so does the likelihood of interpreting noxious stimuli as pain $[17,18]$. It is known that individuals who show general higher anxiety states in their daily lives tend to be more sensitive and reactive to pain than their less anxious counterparts. In addition, during a situation of heightened anxiety, the pain threshold is lowered for all population. Therefore, lowering anxiety levels puts patients at ease and consequently helps them tolerate their own subjective experience of pain.

Our study was conducted to assess the relationship between pain and anxiety during dental extraction. The calculated value of $\left(\chi^{2}\right)$ is greater than the table value, so the null hypothesis is rejected. From the data, we can therefore conclude that there is association between pain and anxiety level. The correlation between pain and anxiety is 0.605 . It reveals that there is a high degree of positive correlation between these two variables. Hence, the pain level depends on anxiety level. If the anxiety level increases, the pain levels will be increased.

\section{Relationship of anxiety to pain}

While some studies have found a significant association between gender and level of dental anxiety, females being more anxious than males [19,20], others have not found this association [9,21]. In our study, we did not find any significant association between gender and dental anxiety. Thomas et al. [22], from their study, concluded that high prevalence of depression and anxiety produced a stress response, which triggered a cascade of events resulting in a series of changes in human vital physiological functions such as blood pressure, respiratory rate, and heart rate and they were significantly higher than normal values.

Table 10: Variables entered/removed

\begin{tabular}{llll}
\hline Model & Variables entered & Variables removed & Method \\
\hline 1 & Anxiety $^{\mathrm{b}}$ & & Enter \\
\hline
\end{tabular}

${ }^{\mathrm{a}}$ Dependent variable: Pain, ${ }^{\mathrm{b}}$ All requested variables entered

Table 11: Model summary

\begin{tabular}{lllll}
\hline Model & $\mathbf{R}$ & $\mathbf{R}^{2}$ & Adjusted $\mathbf{R}^{2}$ & $\begin{array}{l}\text { Standard error of } \\
\text { the estimate }\end{array}$ \\
\hline 1 & $0.616^{\mathrm{a}}$ & 0.379 & 0.368 & 2.096 \\
\hline
\end{tabular}

aPredictors: (Constant), anxiety

Table 12: ANOVA ${ }^{\mathrm{a}}$

\begin{tabular}{llllll}
\hline Model & $\begin{array}{l}\text { Sum of } \\
\text { squares }\end{array}$ & df & $\begin{array}{l}\text { Mean } \\
\text { square }\end{array}$ & F & Signification \\
\hline 1 Regression & 155.425 & 1 & 155.425 & 35.385 & $0.000^{\mathrm{b}}$ \\
$\quad \begin{array}{l}\text { Residual } \\
\text { Total }\end{array}$ & 254.758 & 58 & 4.392 & & \\
\hline
\end{tabular}

${ }^{a}$ Dependent variable: Pain, ${ }^{b}$ predictors: (constant), anxiety
Kain et al. [23] conducted a study to determine if post-operative pain could be predicted based on pre-operative anxiety and their results showed positive correlations between the level of anxiety and post-operative pain. Various other studies established the same results [24,25]. Psychiatric and psychosomatic manifestation of increased pain from heightened anxiety is well established [26]. These study results are in accordance to our study. In contrary, a study showed no correlation between pre-operative anxiety and post-operative pain in patients undergoing major surgeries [27].

Anxiety is thought to influence the effective component of pain [28]. Anxious people tend to overestimate the intensity of aversive events such as fear and pain [29]. Canakçi and Canakçi noted that a patient with a high Corah's dental anxiety scale (DAS), score would be more likely to present a high pain response than a patient with a lower DAS score [30]. Other studies have also reported that people with higher scores on scales measuring dental anxiety and pain reported more pain after dental treatment $[3,31]$.

Klages et al. showed that subjects expected more pain than they experienced and this effect was stronger in patients with higher dental anxiety scores [5]. It was also suggested that anxiety has an influence on the expected pain but not on the experienced pain [32]. According to Fagade and IIe-Lfe [33], if the anxiety scores are high, then there is a corresponding significant increase in the pain VAS scores. Similarly, Vassend [34] reported that increased level of dental anxiety before dental treatment was associated with increased intra-operative pain perception, thus suggesting a strong relationship between the patient's anxiety state before dental extraction and their perception of pain intraoperatively.

Mehrstedt et al. in their study on oral health related quality of life in patients with dental anxiety, found a close association between anxiety and pain before during and after dental procedures. There was prevalence of pain in patients with dental anxiety [35]. In another study, it was shown that pain felt during dental injections was dependent on dental anxiety levels [36]. Post-operative pain is also dependent on dental anxiety as shown by a study on pain after wisdom tooth removal [37]. Pain and dental anxiety is intertwined, influencing each other substantially. According to van Wijk and Hoogstraten people who are predisposed to responding fearfully to pain are at an increased risk of ending up in a vicious circle of anxiety, fear of pain, and avoidance of dental treatment which could, in turn, affect the dental treatment plan [36].

The fear of pain during treatment has been identified as a major factor in preventing patients from seeking dental care. Therefore, delivering dental care with minimal patient discomfort should be an essential part of a clinician's skills to avoid noncompliance. Thus, there exists a need for the dentist to be aware of patient anxiety to effectively deal with it. Hence, assessing the patient's level of anxiety using a questionnaire before dental treatment can lead to modification of the treatment plan as needed [38]. Clinicians should have the ability to reduce patients' fear, discomfort and pain during dental extractions for successful treatment which can be achieved using pharmacologic and/or nonpharmacologic therapies. Conscious sedation is a very useful tool during dental extractions in anxious patients.

\section{CONCLUSION}

Pre-operative dental anxiety is a major predictor of pain experienced by patients during dental extractions. Hence, it is important to reduce

Table 13: Coefficients ${ }^{\mathrm{a}}$

\begin{tabular}{|c|c|c|c|c|c|}
\hline \multirow[t]{2}{*}{ Model } & \multicolumn{2}{|c|}{ Unstandardized coefficients } & \multirow{2}{*}{$\begin{array}{l}\text { Standardized coefficients } \\
\text { Beta }\end{array}$} & \multirow[t]{2}{*}{$\mathbf{t}$} & \multirow[t]{2}{*}{ Signification } \\
\hline & B & Standard error & & & \\
\hline \multicolumn{6}{|l|}{1} \\
\hline (Constant) & 2.256 & 0.591 & & 3.814 & 0.000 \\
\hline Anxiety & 1.804 & 0.303 & 0.616 & 5.949 & 0.000 \\
\hline
\end{tabular}

aDependent variable: Pain, VAS: Visual analog scale 
anxiety before treatment to reduce pain during treatment. To improve the quality of the care provided to the patients in the dental office, the importance of dental anxiety pain relationship must be understood by dental surgeons. They need to assess their patients preoperatively for dental anxiety and use appropriate patient management techniques based on the outcomes of the assessment. Pharmacologic modalities like sedation can be used for reducing anxiety and pain related to the treatment in indicated patients.

\section{REFERENCES}

1. Guzeldemir E, Toygar HU, Cilasun U. Pain perception and anxiety during scaling in periodontally healthy subjects. J Periodontol 2008;79(12):2247-55.

2. Tickle M, Milsom K, Crawford FI, Aggarwal VR. Predictors of pain associated with routine procedures performed in general dental practice. Community Dent Oral Epidemiol 2012;40(4):343-50.

3. Maggirias J, Locker D. Psychological factors and perceptions of pain associated with dental treatment. Community Dent Oral Epidemiol 2002;30(2):151-9.

4. Rhudy JL, Meagher MW. Fear and anxiety: Divergent effects on human pain thresholds. Pain 2000;84(1):65-75

5. Klages U, Ulusoy O, Kianifard S, Wehrbein H. Dental trait anxiety and pain sensitivity as predictors of expected and experienced pain in stressful dental procedures. Eur J Oral Sci 2004;112(6):477-83.

6. Okawa K, Ichinohe T, Kaneko Y. Anxiety may enhance pain during dental treatment. Bull Tokyo Dent Coll 2005;46(3):51-8.

7. van Wijk AJ, Makkes PC. Highly anxious dental patients report more pain during dental injections. Br Dent J 2008;205:E7.

8. McNeil DW, Helfer AJ, Weaver BD, Graves RW, Kyle BN, Davis AM. Memory of pain and anxiety associated with tooth extraction. J Dent Res 2011;90(2):220-4

9. Klages U, Kianifard S, Ulusoy O, Wehrbein H. Anxiety sensitivity as predictor of pain in patients undergoing restorative dental procedures. Community Dent Oral Epidemiol 2006;34(2):139-45.

10. Loggia ML, Schweinhardt P, Villemure C, Bushnell MC. Effects of psychological state on pain perception in the dental environment. J Can Dent Assoc 2008;74(7):651-6.

11. Bottan ER, Glio JD, Araújo SM. Ansiedade ao tratamento odontológico em estudantes do ensino fundamental. Pesq Bras Odontoped Clín Integr. 2007;7(3):241-6.

12. Pizer ME, Dubois DD, Chinnis RJ. Declining dental school enrollments. Va Dent J 1982;59(4):34-7.

13. Gale EN. Fears of the dental situation. J Dent Res 1972;51(4):964-6.

14. Gilhotra N, Dhingra D. Neurochemical modulation of anxiety disorders. Int J Pharm Pharm Sci 2010;2 Suppl 1:1-6

15. Thakur S, Srivastava N. An update on neuropathic pain models. Int $\mathrm{j}$ pharm pharm sci 2016;8(6):11-6.

16. da Costa RS, Ribeiro SN, Cabral ED. Determinants of painful experience during dental treatment. Rev Dor São Paulo 2012;13(4):365-70.

17. Sternbach RA. Pain: A Psychophysiological Analysis. New York Academic Press; 1968.

18. Sternbach RA. Pain Patients: Traits and Treatment. New York: Academic Press; 1974.

19. Milgrom P, Weinstein P, Golletz D, Leroux B, Domoto P. Pain management in school-aged children by private and public clinic practice dentists. Pediatr Dent 1994;16(4):294-300

20. Kaakko T, Getz T, Martin MD. Dental anxiety among new patients attending a dental school emergency clinic. J Dent Educ 1999;63(10):748-52

21. Morse Z, Sano K, Fujii K, Kanri T. Sedation in Japanese dental schools. Anesth Prog 2004;51(3):95-101.

22. Thomas A, Dubey SK, Samanta M, Alex A, Jose SP. Assessment of psychological stressors of depression and anxiety using depression anxiety stress scale-21 in South Indian healthy volunteers. Int J Pharm Pharm Sci 2016;8(5):288-95

23. Kain ZN, Sevarino F, Alexander GM, Pincus S, Mayes LC. Preoperative anxiety and postoperative pain in women undergoing hysterectomy. A repeated-measures design. J Psychosom Res 2000;49(6):417-22.

24. Kain ZN, Sevarino F, Pincus S, Alexander GM, Wang SM, Ayoub C, Kosarussavadi B. Attenuation of the preoperative stress response with midazolam: Effects on postoperative outcomes. Anesthesiology 2000;93(1):141-7.

25. Ploghaus A, Narain C, Beckmann CF, Clare S, Bantick S, Wise R, Matthews PM, Rawlins JN, Tracey I. Exacerbation of pain by anxiety is associated with activity in a hippocampal network. J Neurosci 2001;21(24):9896-903.

26. Cooper IS, Braceland FJ. Psychosomatic aspects of pain. Med Clin North Am 1950;34(4):981-93.

27. Kain ZN, Sevarino FB, Rinder C, Pincus S, Alexander GM, Ivy M, Heninger G. Preoperative anxiolysis and postoperative recovery in women undergoing abdominal hysterectomy. Anesthesiology 2001;94(3):415-22

28. Woolgrove J. Pain perception and patient management. $\mathrm{Br}$ Dent J 1983;154(8):243-6.

29. van Wijk AJ, Hoogstraten J. Experience with dental pain and fear of dental pain. J Dent Res 2005;84(10):947-50.

30. Canakçi CF, Canakçi V. Pain experienced by patients undergoing different periodontal therapies. J Am Dent Assoc 2007;138(12):1563-73.

31. Sullivan MJ, Neish NR. Psychological predictors of pain during dental hygiene treatment. Probe 1997;31(4):123-6, 135

32. Rachman S, Arntz A The overprediction and underprediction of pain. Clin Psychol Rev 1991;11(4):339-55

33. Fagade OO, IIe-Lfe FF. Intra-operative pain perception in tooth extraction - Possible causes Int Dent J 2005; 55(4):242-6.

34. Vassend O. Anxiety, pain and discomfort associated with dental treatment. Behav Res Ther 1993;31(7):659-66.

35. Mehrstedt M, John MT, Tönnies S, Micheelis W. Oral health-related quality of life in patients with dental anxiety. Community Dent Oral Epidemiol 2007;35(5):357-63

36. van Wijk AJ, Hoogstraten J. Anxiety and pain during dental injections. J Dent 2009;37(9):700-4

37. Lago-Méndez L, Diniz-Freitas M, Senra-Rivera C, SeoanePesqueira G, Gándara-Rey JM, García-García A. Postoperative recovery after removal of a lower third molar: Role of trait and dental anxiety. Oral Surg Oral Med Oral Pathol Oral Radiol Endod 2009;108(6):855-60.

38. Sharma S, Majumder K, Dayashankara Rao JK, Arya V, Siwach V, Gulia S. Assessment of relationship between pain and anxiety following dental extraction-A prospective study. Pain Stud Treatment 2015;3(3):23-30 